\title{
Analysis on SOM and Available Nutrient of Mountain Red Earth in Karst Area
}

\author{
Mengjing Xiao \\ School of Tourism and Geographical Science \\ Yunnan Normal University \\ Kunming, Yunnan, China \\ E-mail: xiaomengjing@hotmail.com \\ Jiaxue Wang* \\ School of Tourism and Geographical Science \\ Yunnan Normal University \\ Kunming, Yunnan, China \\ * Corresponding Author
}

\author{
Lie Zhang \\ School of Tourism and Geographical Science \\ Yunnan Normal University \\ Kunming, Yunnan, China
}

\author{
Qian Zhao \\ School of Tourism and Geographical Science \\ Yunnan Normal University \\ Kunming, Yunnan, China
}

\begin{abstract}
Mountain red earth is a kind of relic ancient clay remained on the Yunnan Plateau formed under the influence of paleo climate, but this soil has experienced degradation recently. To understand the mechanism and effects of such degradation, this study examined the mountain red earth based on the analysis of soil organic matter (SOM) and available nutrient. Particularly, soil samples were taken from area covered with pine, shrub land, grassland or uncovered red soil respectively in the karst area of east Yunnan. The results indicated that the highest SOM contents was grassland $(5.00 \%)$, while bare land was the lowest $(1.44 \%)$, a verage contents of vegetated land $(4.48 \%)$ was 3.11 times of bare land; the highest Available K (AK) contents was shrub land $(26.26 \mathrm{mg} / \mathrm{kg})$, while bare land was the lowest $(1.36 \mathrm{mg} / \mathrm{kg})$, average contents of vegetated land $(22.39 \mathrm{mg} / \mathrm{kg}$ ) was 2.75 times of bare land; the highest Available P (AP) contents was grass land $(5.15 \mathrm{mg} / \mathrm{kg})$, while bare land was the lowest $(1.36 \mathrm{mg} / \mathrm{kg})$, average contents of vegetated land $(3.80 \mathrm{mg} / \mathrm{kg})$ was2.79times of bare land. In addition, there was a significant and positive correlation of the contents of SOM with AK and AP. Thus, the red bare soil can be considered as the last stage to the rocky desertification. All these suggest one possible and viable way to improve the structural condition of a layer of red bare soil by increasing the contents of SOM.
\end{abstract}

Keywords- Karst; Mountain Red Earth; SOM; Available nutrient; Rocky Desertification

\section{INTRODUCTION}

Karst eco-system is a special system with low environment capacity, high sensitivity and low stability ${ }^{[1]}$. Soil is the foundation of life, and the transformation mediu $\mathrm{m}$ and force of matter and power, also the key factor of degradation and recovery of karst eco-system. The succession process of vegetation community could be divided into 4 stages: high wood stage- shrub stage-herb stage during the degradation of karst eco-system ${ }^{[2]}$. The basic reas on of soil degradation is nutrient degradation ${ }^{[3]}$. Soil organic matter (SOM)and available nutrient is the index of soil fertility and the key point for vegetation growth. There is a bright red soil with pH value form 4. 20 to 5.72 and no vegetations in the east of Yunnan plateau, China, called "Red Bare Soil Landscape (RBSL)" [3]. Related research indicated that, the SOM and available nutrient of degraded soil and rock desertification area was far lower than those soil covered by vegetation in same region $^{[4-8]}$. This paper discussed the forming reason of RBSL based on the research of surface layer SOM and available nutrient from different vegetation processes and found out the possible solutions to this problem.

\section{MATERIAL AND METHOD}

\section{A. Studyarea survey}

First, confirm that you have the correct template for your paper size. This template has been tailored for output on the US-letter paper size. If you are using A4-sized paper, please close this template and download the file for A4 paper format called "CPS_A4_format".

The template is used to format your paper and style the text. All margins, column widths, line spaces, and text fonts are prescribed; please do not alter them. You may note peculiarities. For example, the head margin in this template measures proportionately more than is customary. This measurement and others are deliberate, using specifications that anticipate your paper as one part of the entire proceedings, and not as an independent document. Please do not revise any of the current designations.

Yunnan Plateau is the west part of Yangtze Para platform which grew since Paleozoic to Triassic from sedimentary cap rock. The middle part of Yunnan Plateau called "Red Plateau" was covered with purple grit stone and the east part was covered with carbonate rocks. The average altitude is $1500 \sim 2000 \mathrm{~m}$, and the northwest part is higher than southeast part. Annual average temperature is $15 \sim 18^{\circ} \mathrm{C}$ with an annual range $12 \sim 16^{\circ} \mathrm{C}$. Average annual rainfall is $1000 \sim 1200 \mathrm{~mm}$, and $80 \% \sim 90 \%$ falls in the May-October period, and decreased form south to northeast. RBSL mainly appeared in karst area form 1100 2500 m. 23000 RBSL spots were proved based on 
spatial resolution satellite image and field investigation. Yunnan pine forest, pyracantha shrub, flat alkaligrass and RBSL patches were small and accompanying with bare rocks.

\section{B. Sampling and analyzing}

14 samples were taken from Xuanwei Country, Fuyuan Country, Zhanyi Country, Shilin Country and Luoping Country using GPS to locate (Tab. 1).
Organic, AP, AK and AN were respectively tes ted by using the methods of hydration heat--photo electricity colorimeters method, $\mathrm{NaHCO}_{3}$ extraction-Mo-Sb colorimetric, NaTPB turbidimetry and alkaline hydrolys is diffusion. The average value was taken from the results of each sample which was tested for 3 times.

TABLE I. BASIC CHARACTERISTICS OF THE TESTED SOILS

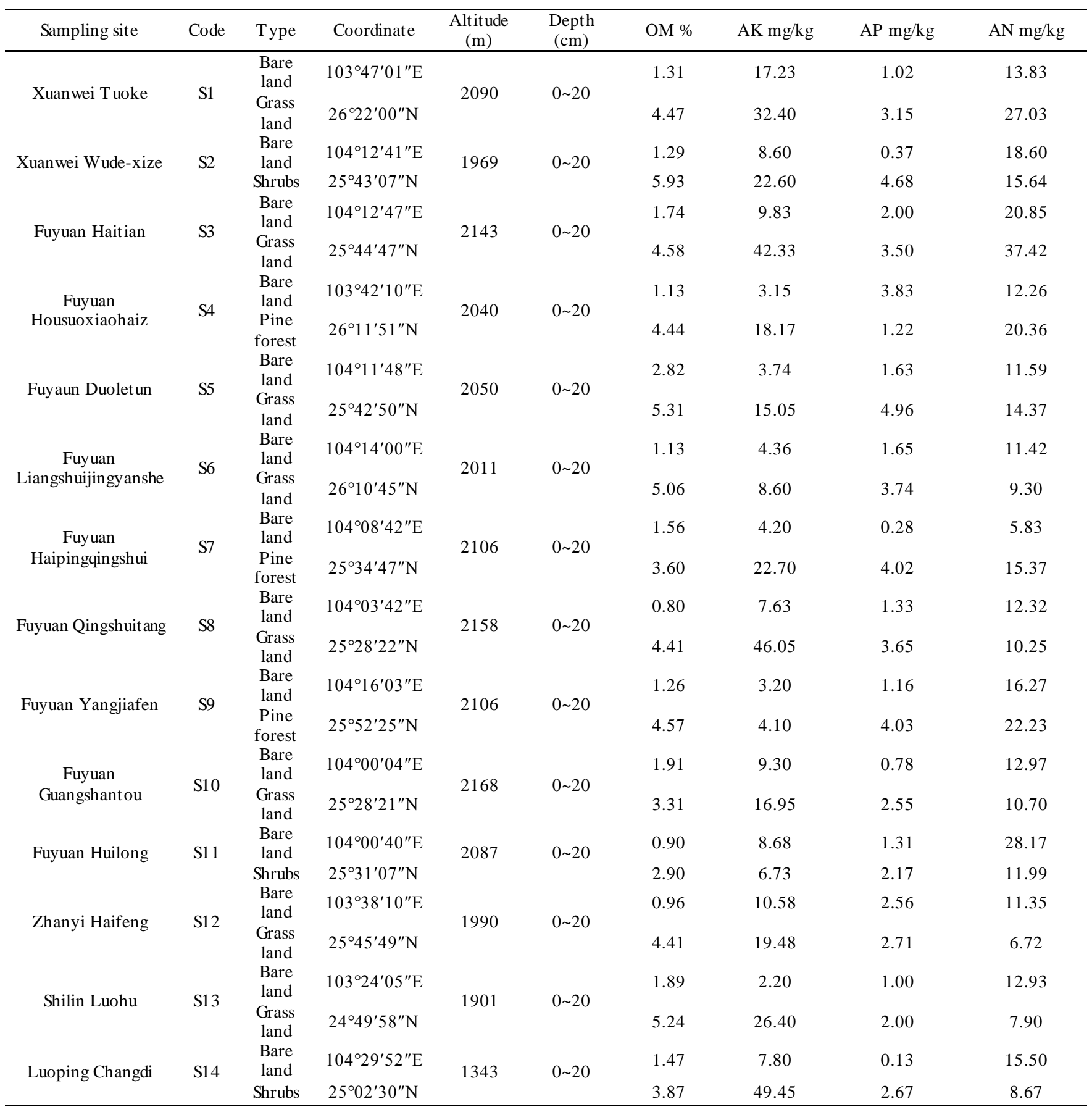




\section{RESULT S AND DISCUSSION}

SOM can keep and improve the soil fertility, soil water permeability, water capacity, soil aeration and soil buffer ability. In addition, it has a positive correlation with soil aggregate stability. The maximum SOM contents was grass land $(5.00 \%)$, followed by shrub land $(4.23 \%)$ and pine forest $(4.20 \%)$, the minimum was bare land(1.44\%). The average SOM contents of vegetation land were $4.48 \%$ which was 3.11 times of that of bare land (Fig. 1, Tab. 2).

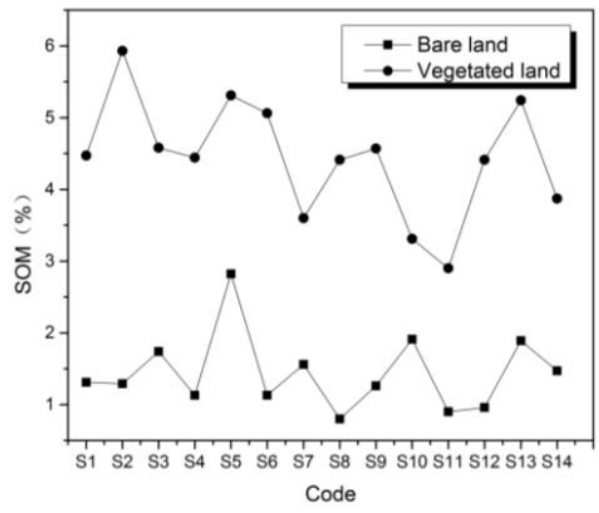

Figure 1. SOM contents comparison of different vegetation types

Soil nutrient, especially available nutrient determined whether the soil is suitable for vegetation or not, moreover, it also influenced the kind of vegetation types. The maximu $\mathrm{m}$ AK contents was shrub land (26.26 $\mathrm{mg} / \mathrm{kg}$ ), followed by grass land and pine forest, the minimum was bare land $(8.13 \mathrm{mg} / \mathrm{kg})$. The average $\mathrm{AK}$ contents of vegetation land were $22.39 \mathrm{mg} / \mathrm{kg}$ which was 2.75 times of that of bare land (Fig. 2, Tab. 2).

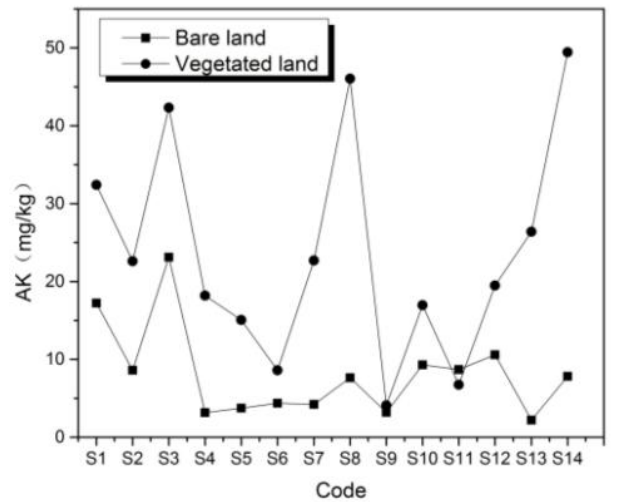

Figure 2. AK contents comparison of different vegetation types

The maximum AP contents was grass land (5.15 $\mathrm{mg} / \mathrm{kg}$ ), followed by shrub land and pine forest, the minimum was bare land $(1.36 \mathrm{mg} / \mathrm{kg})$. The average AP contents of vegetation land were $3.80 \mathrm{mg} / \mathrm{kg}$ which was 2.79 times of that of bare land (Fig. 3 Tab. 2).

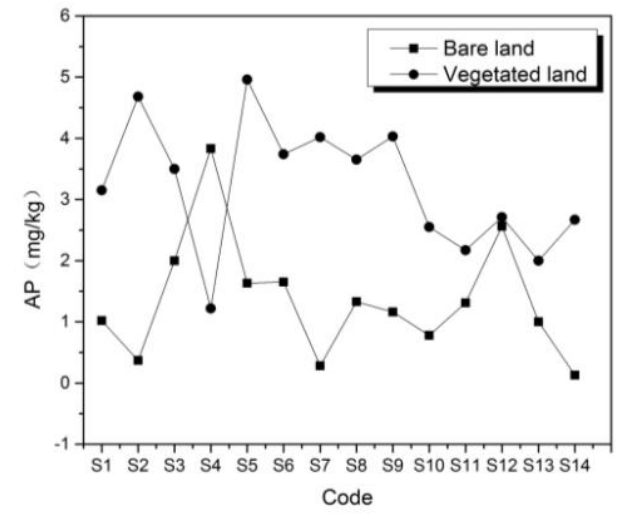

Figure 3. AP contents comparison of different vegetation types

The maximum AN contents was pine forest (19.32 $\mathrm{mg} / \mathrm{kg}$ ), followed by bare land and grass land, the minimum was shrub land $(12.17 \mathrm{mg} / \mathrm{kg})$. The average AN contents of vegetation land was $13.85 \mathrm{mg} / \mathrm{kg}$ which was slightly lower than bare land $(14.08 \mathrm{mg} / \mathrm{kg}$ ) (Fig. 4, Tab. 2).

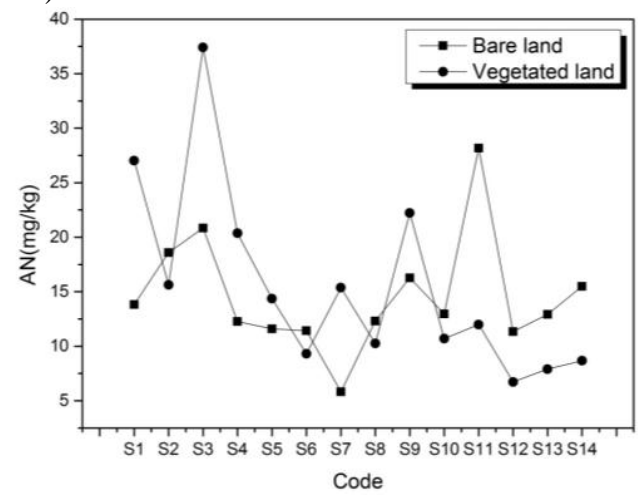

Figure 4. AN contents comparison of different vegetation types

The highest SOM and available nutrient contents was grass land followed by shrubs and pine forest, bare land was the lowest one, except AN. The results was different from the research of other karst area which forest land was the highest one ${ }^{[9]}$. But the soil surface anti-erosion soil aggregate stability of this area show the same results of this paper ${ }^{[10]}$. Compare with forest, especially pine forest, grass needs fewer nutrients, moreover, it returns fast to the soil in a short term than forest and shrubs. Thus, keep the original vegetations and recover the bare land with grass first might be the way of increase soil nutrient.

TABLE II. NUTRIENT CONTENTS OF DIFFERENT VEGETATION TYPES

\begin{tabular}{cccccc}
\hline Type & Samples & SOM $\%$ & AK mg/kg & $\begin{array}{c}\text { AP } \\
\mathrm{mg} / \mathrm{kg}\end{array}$ & AN mg/kg \\
\hline $\begin{array}{c}\text { Pine } \\
\text { forest }\end{array}$ & 3 & $4.20 \pm 0.53$ & $14.99 \pm 9.70$ & $3.09 \pm 1.62$ & $19.32 \pm 4.55$ \\
Shrubs & 3 & $4.23 \pm 1.55$ & $26.26 \pm 21.59$ & $3.17 \pm 1.33$ & $12.17 \pm 4.37$ \\
$\begin{array}{c}\text { Grass } \\
\text { land }\end{array}$ & 8 & $5.00 \pm 0.64$ & $25.91 \pm 13.40$ & $5.15 \pm 5.60$ & $12.23 \pm 3.60$ \\
$\begin{array}{c}\text { Bare } \\
\text { land }\end{array}$ & 14 & $1.44 \pm 0.53$ & $8.13 \pm 5.88$ & $1.36 \pm 0.98$ & $14.08 \pm 1.54$ \\
\hline
\end{tabular}


SOM contents of vegetation land was level 1 and AP was level 5, by contrast, SOM contents of bare land was level 4 and level 6. Meanwhile, AK and AN contents of both vegetation land and bare land in this area was level 6 which was very low.

TABLE III. THE SECOND NATIONAL SOIL SURVEY STANDARD

\begin{tabular}{|c|c|c|c|c|}
\hline Level & $\underset{\%}{\mathrm{SOM}}$ & $\begin{array}{c}\mathrm{AK} \\
\mathrm{mg} / \mathrm{kg}\end{array}$ & $\begin{array}{c}\mathrm{AP} \\
\mathrm{mg} / \mathrm{kg}\end{array}$ & $\begin{array}{c}\mathrm{AN} \\
\mathrm{mg} / \mathrm{kg}\end{array}$ \\
\hline $\begin{array}{l}\text { 1(very } \\
\text { high) }\end{array}$ & $>4$ & $>200$ & $>40$ & $>150$ \\
\hline 2(high) & $3 \sim 4$ & $150 \sim 200$ & $20 \sim 40$ & $120 \sim 150$ \\
\hline $\begin{array}{l}\text { 3(mediu } \\
\text { m-high) }\end{array}$ & $2 \sim 3$ & $100 \sim 150$ & $10 \sim 20$ & $90 \sim 120$ \\
\hline $\begin{array}{l}4(\text { mediu } \\
\text { m-low) }\end{array}$ & $1 \sim 2$ & $50 \sim 100$ & $5 \sim 10$ & 60 90 \\
\hline 5 (low) & $0.6 \sim 1$ & $30 \sim 50$ & $3 \sim 5$ & $30 \sim 60$ \\
\hline $\begin{array}{l}\text { 6(very } \\
\text { low) }\end{array}$ & $<0.6$ & $<30$ & $<3$ & $<30$ \\
\hline
\end{tabular}

A. Correlation analysis between SOM and available nutrient

The results shows that, there was a significant positive correlation between SOM and $\mathrm{AP}(\mathrm{R}=0.0 .49)$, and positive correlation between SOM and $\mathrm{AK}(\mathrm{R}=0.57)$, but there was non-significant correlation between SOM and $\mathrm{AN}(\mathrm{R}=-0.03)$. Thus, increasing $\mathrm{SOM}$ has a positive effect on keeping AP and AK.

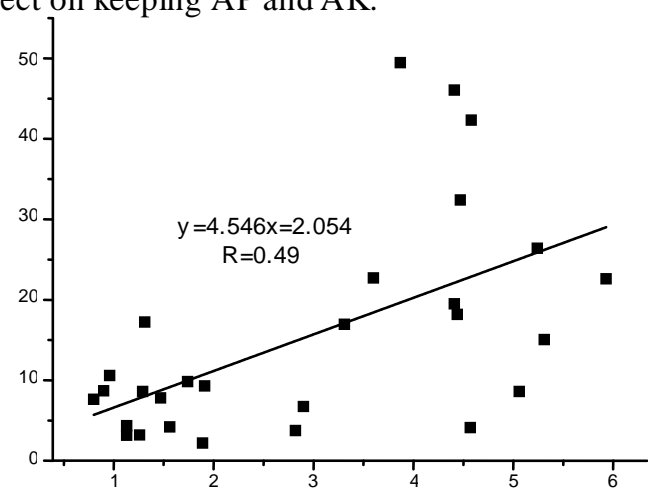

Figure 5. Correlation between SOM and AP

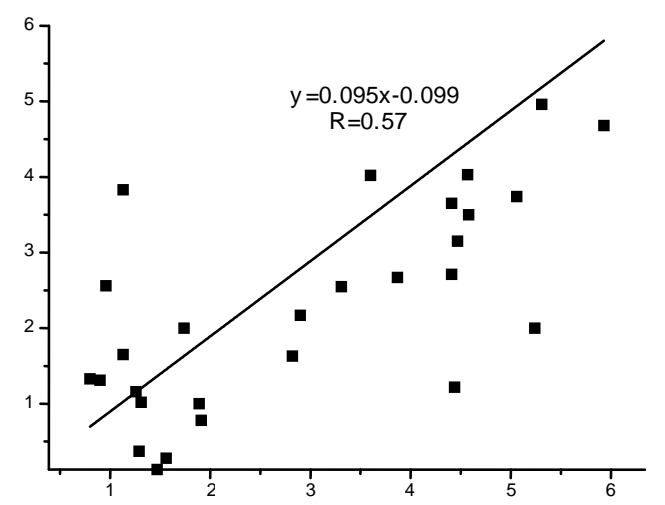

Figure 6. Correlation between SOM and AK

\section{CONCLUSIONS}

The results indicated that the highest SOM contents was grassland $(5.00 \%)$, while bare land was the lowest $(1.44 \%)$, average contents of vegetated land (4.48\%) was 3.11 times of bare land; the highest Available K (AK) contents was shrub land $(26.26 \mathrm{mg} / \mathrm{kg})$, while bare land was the lowest $(1.36 \mathrm{mg} / \mathrm{kg})$, average contents of vegetated land $(22.39 \mathrm{mg} / \mathrm{kg})$ was 2.75 times of bare land; the highest Available P (AP) contents was grass land $(5.15 \mathrm{mg} / \mathrm{kg})$, while bare land was the lowest $(1.36$ $\mathrm{mg} / \mathrm{kg})$, average contents of vegetated land $(3.80 \mathrm{mg} / \mathrm{kg})$ was2.79times of bare land. In addition, there was a significant positive correlation between SOM and AK, and positive correlation between SOM and AP. All these suggest one possible and viable way to improve the structural condition of a layer of red bare soil by increasing the contents of SOM from keeping the original vegetation and recovering the bare land with grass first which helps SOM accumulation, in addition, helps increase the content of AK and AP.

\section{ACKNOWLEDGMENT}

This work is supported by Special Science and Technology Plan of Yunnan Province (2012CA024) and National Natural Science Foundation of China (41061021).

\section{REFERENCES}

[1] Zhang PJ, Pan GX (2012) Characteristics of soil nutrients and biochemical properties under different vegetation communities in karst area. Journal of Soil and Water Conservation 26(1):7784.

[2] Liu F, Wang SJ, Liu YS, He TB, Luo HB, Long J (2005) Changes of soil quality in the process of karst rocky desertification and evaluation of impact on ecological environment. ActaEcologica Sinica 25(3):639-644.

[3] Liu CQ, Lang YC, Li SL, Piao HC, Liu TZ, Zhang W, Zhu SF (2009) Researches on biogeochemical processes and nutrient cycling in karstic ecological systems, southwest China:A review. Eerth Science Frontiers 16(6):1-12.

[4] Chen H, Wang JX, Hu CC, Ma ZL (2012) Oganic matter content of the bare lateritic surface-layer in east Yunnan karst rocky deserts. Carsologica Sinica 31(4):423-425.

[5] Hu CC, Wang JX, Chen H(2012) Relationships between soil organic matter content and $\mathrm{pH}$ in topsoil of rocky desertification area associated with red-bare-soil in eastern Yunnan. Yunnan Geographic Environment Research 24(4):98-103.

[6] Long J, Huang CW, Li J(2002) Effects of land use on soil quality in karst hilly area. Journal of Soil and Water Conservation 16(1):76-79.

[7] Long HF, Su WC(2013) Analysis on soil nutrient change of different slope positions in karst desertification area. Guizhou Science 31(3):30-35.

[8] Zhou LC, Chen XM, Li XL, Yang XQ, Huang DM(2009) Variability of soil nitrogen in karst regions under typical rocky desertification stage, southwest China 28(8):1753-1757.

[9] Zhang TL, Lu RK, Li ZP(1998) Nutrient degradation and restoration of red soil in hilly region of China. Resources and Environment in the Yangtza Basin7(1):18-24.

[10] Zhang L, Wang JX, Liu BQ, Xiao MJ, Cheng YF, XU LY(2015) The variation of surface soil aggregates in the degradation process of the mountain red earth zone karst. Journal of Mountain Science 33(1): 8-15. 